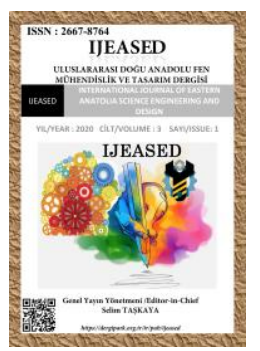

IJEASED INTERNATIONAL JOURNAL OF EASTERN ANATOLIA SCIENCE ENGINEERING AND DESIGN

\author{
Uluslararası Doğu Anadolu Fen Mühendislik ve Tasarım Dergisi \\ ISSN: 2667-8764, 3(1), 282-297, 2021 \\ https://dergipark.org.tr/tr/pub/ijeased
}

Araştırma Makalesi / Research Article

Doi: $\underline{10.47898 / \text { ijeased.824314 }}$

\title{
İmgesel Yapılarda Müzik ve Geometri Kesişimi; Iannis Xenakis Örnekleri Üzerinden İnceleme
}

\author{
Burcu Buram ÇOLAK ${ }^{1 a^{*}}$, Zeynep Yeşim İLERISOY ${ }^{1 \mathrm{~b}}$, Asena SOYLUK ${ }^{1 \mathrm{c}}$
}

${ }^{1}$ Gazi Üniversitesi, Mimarlık Fakültesi, Mimarlık Bölümü, Ankara, 06570, Türkiye.

\begin{tabular}{|c|c|c|}
\hline Yazar Kimliği / Author ID (ORCID Number) & \multicolumn{2}{|c|}{ Makale Süreci / Article Process } \\
\hline 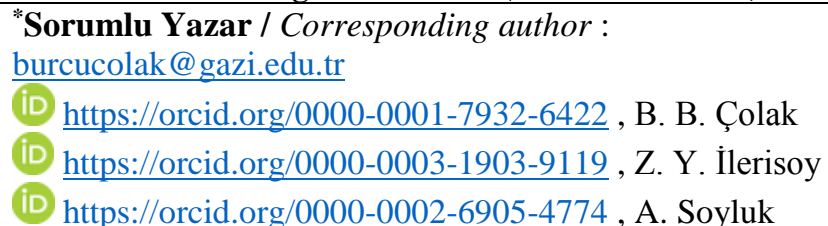 & $\begin{array}{l}\text { Geliş Tarihi / Received Date : } \\
\text { Revizyon Tarihi / Revision Date : } \\
\text { Kabul Tarihi / Accepted Date : } \\
\text { Yayım Tarihi / Published Date : }\end{array}$ & $\begin{array}{l}11.11 .2020 \\
06.02 .2021 \\
08.04 .2021 \\
15.07 .2021\end{array}$ \\
\hline
\end{tabular}

Alıntı / Cite: Çolak, B.B., İlerisoy, Z.Y., Soyluk, A. (2021). İmgesel Yapılarda Müzik ve Geometri Kesişimi; Iannis Xenakis Örnekleri Üzerinden İnceleme, Uluslararası Doğu Anadolu Fen Mühendislik ve Tasarım Dergisi, 3(1), $282-297$.

\section{Özet}

Disiplinler arası olan mimarlığın müzik ile ilişkisi tarih boyunca sorgulanmıștır. Her iki disiplinin matematik kurgularının kendine özgü olmasının yanı sıra derinlemesine incelendiğinde bu kurguların alt taban verilerinin aynı kaynaktan geldiği görülmektedir. Çalışma kapsamında; müzik mimarlık ilişkisi müzisyen bir mimar olan Iannis Xenakis 'ın tasarlamış olduğu örnekler üzerinden; müzik ile mimarlık ilişkisinin nasıl kurulduğunun anlaşılması için yapı künyeleri oluşturulup, mimari özellikleri ve tasarım yaklaşımları araştırılmıştır. Daha sonra oluşturulan tablolar yardımıyla çalışma kapsamında incelenen örnekler belli başlıklar altındaki parametreler aracığıyla irdelenmiştir. Müzik ve mimarlık disiplinlerinin ara kesitindeki temel kriterler; mimarlık ve müzikte kompozisyon ile ilgili temel kavramlar, tasarım yaklaşımda vurgu, mimarlık ve müziğin tasarımdaki kurgusu, tasarımın çıkış noktası, müzik ve mimarlık ilişkisi kompozisyonu oluşturmada kullanılan yapı elemanları şeklinde ana başlıklarda toplanmıştır. Bu ana başlıkların alt başlıkları olarak ortak parametreler doğrultusunda irdelenen örnekler üzerinde müzik ve mimarlık ilişkisini tasarımda kurgularken nelere dikkat edildiği, tasarım amacına uygun olarak hangi kriterlerin ön plana çıktığına dikkat çekilmesi hedeflenmektedir. Sonuç olarak; mimar bir müzisyen olan tasarımcı Iannis Xenakis 'ın yapılarında müzik ile mimarlık ilişkisini kurgularlarken kullandığı parametrelerin neler olduğunun ortaya koyulması sağlanarak bir yapıda müzik ile ilişki kurulurken matematiksel kurgunun nasıl strüktüre edilmesi gerektiği konusunda literatüre katkı sağlanması amaçlanmıştır.

Anahtar Kelimeler: Müzik, Mimarlık, Geometri, Iannis Xenakis, Müzik ve Geometri. 


\title{
Music and Geometry Intercept in Imaginary Structures; Review Through Iannis Xenakis Examples
}

\begin{abstract}
The relationship of interdisciplinary architecture with music has been questioned throughout history. In addition to the fact that the mathematical constructs of both disciplines are unique, it is seen that the subbase data of these mathematical constructs, which appear to be unique when examined in depth, come from the same source. Scope of work; The relationship between music and architecture is based on examples designed by Iannis Xenakis, a musician architect; In order to understand how the relationship between music and architecture was established, building tags were created and architectural features and design approaches were investigated. Then, with the help of the tables created, the examples examined within the scope of the study were examined by means of parameters under certain headings. Basic criteria in the intersection of music and architecture disciplines; Basic concepts related to composition in architecture and music, emphasis in design approach, fiction of architecture and music in design, starting point of design, building elements used in composing the relationship between music and architecture. As the sub-headings of these main headings, it is aimed to draw attention to what is taken into consideration while constructing the relationship between music and architecture in design, and which criteria come to the fore in accordance with the design purpose, on the examples examined in line with common parameters. As a result; it is aimed to contribute to the literature about how the mathematical construct should be structured while establishing a relationship with music in a building by revealing the parameters used by Iannis Xenakis, an architect musician, while constructing the relationship between music and architecture in his buildings.
\end{abstract}

Keywords: Music, Architecture, Geometry, Iannis Xenakis, Music and Geometry.

\section{Giriș}

Bir yapıyı meydana getiren birimlerinin ölçülerinin doğru kurgulanması; yapının insan ölçeği ve çevresi ile uyumlu olması ile mümkündür. Müziğin ölçülü olması söz konusu olduğunda ise notaların bir araya gelişi ile bir beste tasarımı strüktürünün oluşturulması ile mümkün olmaktadır. Müzik ve mimarlık alanları; geometri ve analizler yardımı ile sayısız kombinasyon oluşturmaya imkân sağlamaktadır. Bu sayede kendi içerisinde bir düzen oluşturabilmektedir. Oluşturulan bu düzenin nasıl meydana geldiğinin kurgusunun daha iyi anlaşılması açısından öncelikle müzik ve mimarlık ilişkisi hakkında gerekli literatür araştırmaları yapılmıştır. Literatür araştırmasında müziğin görselleştirilmesi, müziğin geometrisi ve altın oran, müzik ile mimarlık ilişkisi, müzik ve mimarlıkta sayısal - geometrik arakesit konularına yer verilmiştir. Mimari uygulamalarda müziğin nasıl yer bulduğu hakkında yapılan araştırmalar ile konu ele alınmıştır. Çalışma kapsamında müzisyen bir mimar olan Iannis Xenakis'ın tasarlamış olduğu yapı örnekleri temel tasarım parametreleri yardımıyla değerlendirilmiştir.

Kültürel olarak anlam yüklü sesler içinde kalıplaşan bir etkinlikler, düşünceler ve nesneler bütünü olan müzik; duygu, düşünce, tasarım ve izlenimleri belirli bir amaç ve yöntemle belirli bir 
güzellik anlayışına göre birleştirilmiş seslerle işleyip anlatan estetik bir bütün ve seslerle düşünme, sesler aracılığıyla yaşamı duyumsama sanatıdır (Canbay, Alaattin vd., 2013).

İnsanlık tarihinin başlangıcından beri var olan müziğin temel yapı malzemesi olan sesin işlenmesi, doğadaki seslerin dinsel ayinlerde kullanmasıyla başlanmıştır. Müziğin orijinal haliyle gelecek nesillere aktarılması ve öğrenilebilmesi için farklı zaman ve kültürlerde birbirinden değişik türde müziği yazı ile ifade şekilleri ortaya çıkmıştır (Güngör, 2015). Müzik yazısının bulunmasının en önemli sebeplerinden biri geliştirilmesi ve öğrenilmesi için sesleri duyumsamanın dışında kalıcı bir veriye ihtiyaç duyulmasıdır.

Tarih boyunca yapılan bütün çalışmalar içerisinde müziğin görselleştirilmesi konusunda en basit ve yaygın olan notasyon sistemi; nota yazılırken sözlerin yazıldı̆̆ı harflerin üzerine sesleri hatırlatıcı nitelikteki bazı işaretlerin konulması konusunda kullanılan ilk yöntemdir.

Latince notare (kaydetmek, işaretlemek, işaret koymak) anlamındaki sözcükten türemiş olan notasyon, sesin nitelik, gürlük, hız, yükseklik ve süre gibi her türlü anlatım özelliğini aktarmayı amaçlayan, sesleri ve seslerin hareketlerini işaretlerle belirten yazı dizgesidir (Say, 2002: 368). Porte üzerine yazılan, bir müzik sesini belirtmeye yarayan nota; müzik eserlerinin yazılmasına ve okunmasına yarayan işaretlerdir. Bugünkü bilinen ve kullanılan şekline gelinceye kadar pek çok değişiklik geçirmiş olan müzik yazısı, ortaya çıkışından bu yana alfabetik, neumatigue (işaret), oransal (kare) ve oval (bugünkü) olmak üzere farklı biçimlerde kullanılmıştır (Akkaş, 2000 s.67). Toplumların sosyal, kültürel gelişimleri ve değişimleriyle müzik alanında da tür ve çeşitliliğinin artması, müzik aleti üretiminde zamanla gelişen teknolojinin de etkisiyle müzik yazısı da değişmiş ve günümüzdeki halini almıştır.

Nota tarihçesi geçmişten günümüze incelendiğinde dört farklı nota yazım yaklaşımının (harf yazıları, harf-şekil yazıları (neumatik), dizekli nota yazıları ve tabulaturalar) ortaya çıktığı görülmektedir. Bu yazım türlerinin ilk örnekleri MÖ. 1500'lü yıllarında Sümerlere ait tabletlerinde bulunmuştur (Bent, 1991). Alfabeler kadar eski olduğu bilinen notalama sistemlerinin ilk yazım yaklaşımı olan harf yazıları; Sümerleri takiben Babillerin daha sonrasında eski Mısırlıların, buradan İbraniler ve sonraları Habeşler gibi diğer Sami kavimlerinin de kullandıkları bilinmektedir. Müzik yazısı daha sonraları Aramiler ve Süryaniler tarafından geliştirilip diğer Mezopotamya medeniyetlerinde farklı kültürlerde değişiklikler eklenerek yayılmıştır. Müzik yazısındaki bu gelişmeleri takiben önce Girit'e ve İyonya'ya gelen nota yazısı daha sonraları Yunanistan'da da kullanılmaya başlanmıştır (Ak, 2009, s.28-29). Harf yazıları nota yaklaşımı M.Ö. 1400'den M.S. 10. yüzyıla kadar, neumatik sistemin ise 9. ve 12. yüzyıllar arasında Batı Avrupa, Bizans, Doğu Avrupa, 
Japonya ve Tibet’te oluşturulmuş ve kullanılabilir boyuta geldiği bilinmektedir (Bent, 1991). Müzik yazısının bu zamana kadar gelişimi ve değişiminden nasibini alan eski Türk müzik eserlerinin günümüze ulaşması Osmanlı İmparatorluğunda da III. Selim (Selim-i Salis) zamanında, Hamparsum Limonciyan 'ın geliştirdiği bir notalama sistemi sayesinde sağlanmıştır. Bu notalama sistemi ile eski eserleri anlamak, analiz edebilmek ve öğrenmek mümkün kılınmıştır. Hamparsum Limonciyan '1n geliştirdiği notalama sistemi Şekil 1'de görülmektedir.

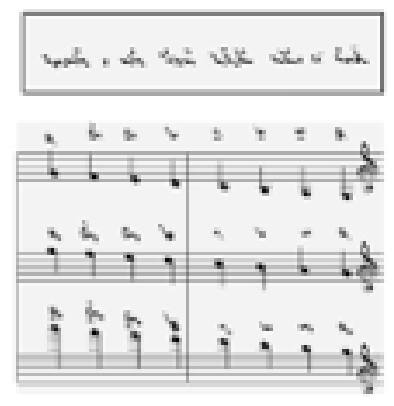

(a)

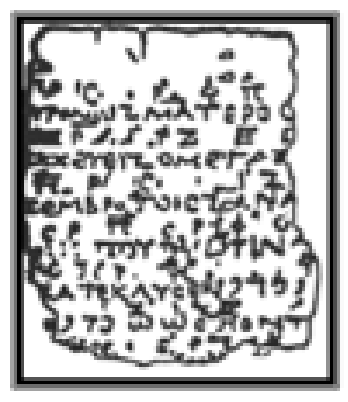

(b)

Şekil 1. (a) Sümer uygarlığına ait müzik yazımı, (b) Hamparsum Limonciyan, notalama sistemi (Güran, 2008)

Güncel olarak kullanılan 'Siyah Ölçülü Notalama' müzikte notaların içlerinin doldurulması ile başlanarak porteli nota adlandırması ile şu an günümüzde karşımıza çıkmaktadır. Müzik yapıtlarının okunabilirliği ve dinlenilebilirliğinin yaygınlaşması, ses tekniklerinin geliştirilmesi, notaların tarih içerisinde kat ettiği önemli yol, müzik kompozisyonu alanındaki büyük ilerlemeler sayesinde müzik yaygınlaşmıştır (Mimaroğlu, 1987). Şekil 2'de notalama sistemi görülmektedir.
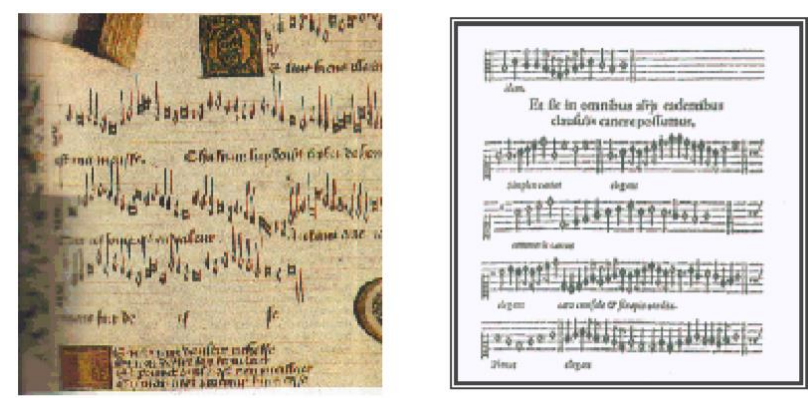

Şekil 2. Güncel Avrupa notalama sistemine yakın, kilise müziği notaları (URL-1).

Müziğin geometrik temsili müzikteki motiflerin geometrik analizi yapılarak, bu analizin geometriye dönüştürülmesiyle mümkündür. Bilgisayar destekli performans programları aracılığıyla bir bestenin matematiksel strüktürünü analiz ederek yapıtın daha derin anlaşılması sağlanmaktadır. Günümüzde müzik eserlerinin anlaşılması için herkesin kullanabileceği notaları basit grafiksel anlatımlara döken yazılımlar geliştirilmiştir. $\mathrm{Bu}$ sayede daha basit bir şekilde müziği geometriye 
dönüştürmek mümkün kılınmıştır (Cage 1955). Müziğin geometriye dönüştürülmesi ile farklı disiplinler ile müziğin ilişkilendirilmesi konusu çeşitlilik kazanmıştır.

Müziğin geometriye dökülmesi ile bu geometrinin çeşitli tasarı alanlarında kullanımı sağlanmıştır. Müzik yapıtlarının incelenmesi ile geometrilerde altın oran kurgusuna sıklıkla rastlanılmıştır. Mimarlığın farklı katmanlarında karşımıza çıkan altın oran ilişkisi Dürer'in “çember içinde insan" çizimi ile Şekil 3’te altın oranın müzikteki grafik anlatıma dönüştürülmesi ile elde edilen geometri görülmektedir.

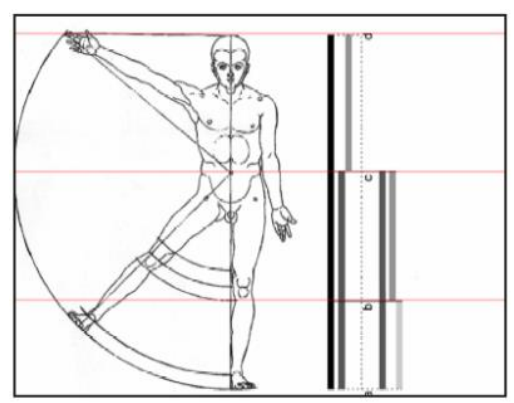

Şekil 3. Dürer'in insan figürü, Altın oran (ca. 1521) (Evans, 1992).

Disiplinler arası olan mimarlığın müzikle ilişkisi irdelendiğinde ikisinin de temelinde yaratma edimi yattığı açıkça görülmektedir. Ritim, ölçü, armoni, kompozisyon gibi evrensel yaratım araçlarını müzikte besteciler ve mimarlık alanında da tasarımcılar kullanmaktadır. Her iki alanın temelinde belirli matematiksel hesaplara dayalı strüktürler mevcuttur. Mimarlık ve müzik disiplinleri biçimler ve biçimlerin birbiri ile kurdukları ilişki sayesinde insanların doğrudan duygularını etkilemektedir (Corbusier, 2001: 33). Müzik ve matematik arasındaki ilişki incelenirken öncelikle matematiksel kurgularını irdelemek gerekmektedir. Matematiksel kurguları analiz edildiği takdirde, biçimler ile kurduğu ilişki ve insan üzerinde bıraktığg etki doğru anlaşılabilmektedir.

Müzikte notaların bir araya gelişi ile ritim, ölçü ve armoni kavramlarının oluşturduğu strüktür bir tasarım iken aynı şekilde mimarlıkta da armoni yapının tüm elemanlarının oranlı, ölçülü olma durumudur (Vitruvius, 2015: 10). Mimarlık ve müzik disiplininin kendine özgü matematik kurgularının teknik verilerinin aynı alt yapıya dayandığını ve kurgu oluşturulurken günümüzde bilgisayar destekli programlardan yararlandığını bilinmektedir (Şentürk, 2004). Bilgisayar destekli programlardan yararlanırken matematik verilerden yararlanılmaktadır. Mimaride sayısal veri olarak müziğin kullanımı bilgisayar destekli tasarım programlarının olmadı̆̆ı, çok eskilere dayanan bir kavramdır. Matematiksel verinin formüle edilip mimari alanda kullanımı doğadaki oranların referans alınmasıyla sağlanmıştır. 
Müzikteki ses dizgelerinin matematiksel yapısının, mimarideki yapı kurgusunun matematiksel yapısı ile ortak çıkış noktası olarak gösterilen 'doğa' ile müzik ve mimarlık disiplinleri arasında oran ve ölçülere dayalı bir dil tasarlanmıştır. Müziğin matematiği doğa ile uyum ve süreklilik sağlayan sayısal veri olarak kullanımının yanı sıra bir bütünü oluşturan küçük parçaların birbiriyle orantıları ve geometrilerinin oluşumunda rol alan modüler parçaları oluşturan bir sistem olarak kullanılmıştır (Erözü, 2008). Şekil 4'te Osmanlı yapı ustası Mimar Sinan'ın eserlerinde notalardan hareketle temel geometrik elemanların kullanımında belli bir sistem içine oturtarak daha gerçekçi bir yaklaşım benimsendiği görülmektedir.
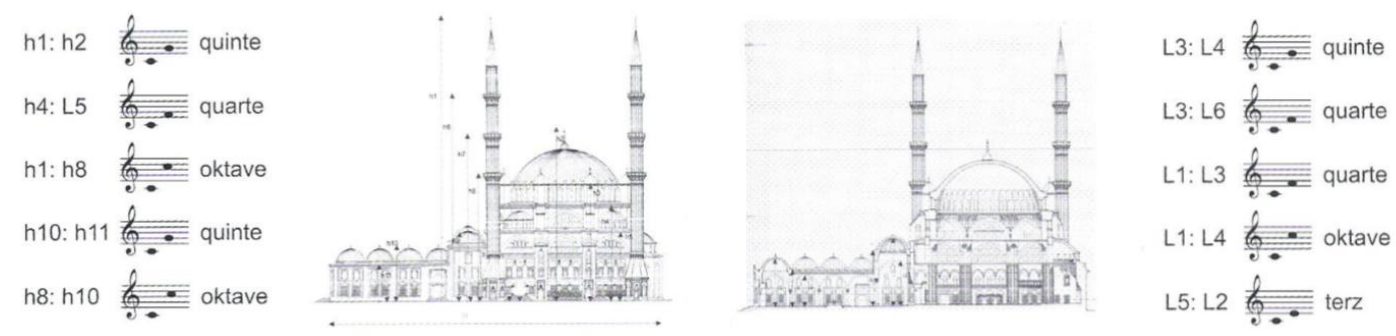

Şekil 4. Selimiye Camii’nin düşey oranlardaki müzikal oranlar (Korkut,2011).

\section{Materyal ve Metot}

Tarih boyunca ilişkisi sorgulanan mimarlık ve müzik disiplinlerinin her ikisinin de matematik kurgularının kendine özgü olmasının yanı sıra derinlemesine incelendiğinde bu kurguların alt taban verilerinin aynı kaynaktan geldiği görülmektedir. Müzikte beste matematiksel verilerle strüktüre edilirken, mimaride yine matematiksel kurallara dayanarak yapı strüktüre edilmektedir. Müzik ve mimarinin geometrik ilişkilerinden doğan tasarıların aralarındaki matematiksel ilişkiyi en iyi yansıtan örnekler mimari alanda bulunmaktadır. Müzik ve mimarlık disiplinleri; geometri, grafikler ve analizler yardımı ile sınırsız sayıda kombinasyon oluşturmaya imkân sağlamaktadır. $\mathrm{Bu}$ nedenle kendi içerisinde oluşturdukları denklemler sayesinde düzen oluşturabilmektedir. Tasarlanan bu düzenlerin kurgularının daha iyi anlaşılması açısından çalışma kapsamında öncelikle; müzik, müziğin kısaca tarihçesi ve müziğin mimarlık ile olan ilişkisi hakkında gerekli literatür araştırmaları yapılmıştır. Literatür araştırması kapsamında; müziğin görselleştirilmesi, müziğin geometrisi ve altın oran, müzik ile mimarlık ilişkisi, müzik ve mimarlıkta sayısal - geometrik arakesit konularına yer verilmiştir. Mimari uygulamalarda müziğin nasıl yer bulduğu hakkında yapılan araştırmalar ile konu ele alınmıştır. 
Gerekli literatür çalışmalarından sonra konu kapsamında; müzisyen bir mimar olan Iannis Xenakis'ın tasarlamış olduğu yapı örnekleri temel tasarım parametreleri yardımıyla değerlendirilmiştir. Mimar olmasının yanı sıra savaş sonrası en önemli avangard bestecilerden biri olarak tanınan Iannis Xenakis mimarlık alanında ilk örneklerini Le Corbusier ile birlikte tasarlamıştır. Müzisyen mimar olan ve müzik ve matematik alanında çokça önemli teorik yazıları ile tanınan Iannis Xenakis yapılarını mimarlık ve müzik ilişkisini yansıtmayı amaçlayarak tasarlamış ve bu bağlamda eserler ortaya koymuştur. Konu kapsamında Iannis Xenakis'ın tasarlamış olduğu müzik ve mimarlık ilişkisini yansıtan en ünlü ve önemli 4 yapı örneği seçilmiştir. Yapı örneklerinden seçim yapılırken; tasarımın müzik mimarlık ilişkisini yansıtma kaygısı ile kurgulanmış olmasına dikkat edilmiştir. Iannis Xenakis'in çalışma için seçilen yapı örnekleri; Isthmia Prime Motel, La Tourette Manastırı, Philips Pavyonu ve Villa Mache 'dir. Örnekler hakkında mimari araştırmalar yapılıp mimari özellikleri ve tasarım aşaması kısaca anlatıldıktan sonra incelenen örnekler için fotoğrafları, çizimleri, yapım yılı, konumu, tasarımda müzik ile ilişkisini vurguladığı nokta, tasarım yaklaşımı ve mimari özelliklerinin yer aldığı bir tablo oluşturulmuştur. Bu tablonun oluşturulmasındaki amaç; seçilen örnek yapıların müzik ile ilişkisinin daha iyi anlaşılmasıdır.

Araştırma kapsamında incelenen yapı örnekleri belli başlıklar altındaki parametreler aracığıyla irdelenmiştir. Bir yapının mimarlık ve müzik ilişkisini tasarımında yansıtabilmesi için bu iki disiplin ara kesitindeki temel kriterlere sahip olması gerekmektedir. Müzik ve mimarlık disiplinlerinin ara kesitindeki temel kriterler; mimarlık ve müzikte kompozisyon ile ilgili temel kavramlar, tasarım yaklaşımda vurgu, mimarlık ve müziğin tasarımdaki kurgusu, tasarımın çıkış noktası, müzik ve mimarlık ilişkisi kompozisyonu oluşturmada kullanılan yapı elemanları şeklinde sıralanmaktadır. $\mathrm{Bu}$ temel kriterler başlıkları altındaki parametreler aracılığıyla irdelenen örnekler üzerinden müzik ve mimarlık ilişkisini tasarımda kurgularken nelere dikkat edildiği, tasarım amacına uygun olarak hangi kriterlerin ön plana çıktığına dikkat çekilmesi hedeflenmektedir. Müzik mimarlık ilişkisi sağlamada bu yaklaşımın tasarımda vurguda cephe, strüktür, form olarak değişkenlik göstermesinin temel kriter başlıkları altındaki parametrelerin gösterdiği değişkenlikle doğrudan ilişkili olduğu görülmektedir. Yapıda müzik mimarlık ilişkisine dikkat çekmek istenilen vurgu parametrelerin hangisinin ön plan çıkması ile ilişkilidir.

Mimarlık ve müzikte kompozisyon ile ilgili temel kavramlar başlığı altında; ritim, armoni, doku ve tema kriterleri ele alınırken tasarım yaklaşımda vurgu başlığı altında strüktür, cephe, form ve plan düzlemi kriterleri yer almaktadır. Mimarlık ve müziğin tasarımdaki kurgusu başlı̆̆ı bir tasarımda mimarlık ve müzik ilişkisi kurgulanırken kurgunun; matematiksel, renk, kopyalama/öykünme ve 
bilgisayar destekli parametrelerinden hangisi ile tasarlandığının belirlenmesi konusunu kapsamaktadır. Kurgu; matematiksel ve bilgisayar destekli verilere dayanabileceği gibi renk ile bir düzen oluşturulup da yansıtılabilmektedir. Ayrıca müzik mimarlık ilişkisini tasarımda vurgulamada kopya / öykünme tekniği de sıkça kullanılan yöntemler arasındadır. Tasarımın çıkış noktası başlığı altında müzisyen çıkışlı, müzik çıkışlı, doğa çıkışlı ve kullanıcı çıkışlı parametreleri yer alırken müzik ve mimarlık ilişkisi kompozisyonu oluşturmada kullanılan yapı elemanları başlığı altında pencere, malzeme, oran, insan ölçeği, şeffaflık, ölçek, geometrik şekiller ve doluluk- boşluk parametreleri yer almaktadır. Ana başlıkların alt parametreleri olarak yer alan kriterlerden hangisinin kullanılıp kullanılmadığı müzik ile mimarlık ilişkisi kurgulanırken tasarımın temel alt veri tabanını oluşturmada önem arz etmektedir. Kompozisyon pencere, malzeme seçimi ile sağlanabileceği gibi cephe ve plan düzlemindeki oran ve ölçekle de sağlanabilmektedir.

İncelenen yapı örnekleri üzerinden tasarımında kurulan disiplinler arası ilişkinin belirlenmesi için temel tasarı parametrelerinden hangisine sahip olduğunun belirlemesi gerekmektedir. Araştırma, müzik mimarlık ilişkisi kurgulanırken tasarımın hangi noktasında bu ilişkiyi yansıtacağımızı belirledikten sonra bu fikir doğrultusunda seçilmesi gereken parametrelerin neler olduğunun belirlenmesi hususunda tasarımcılara yardımcı olabilecek nitelikte ön bilgi vermektedir. Sonuç olarak çalışma; mimar bir müzisyen olan tasarımcı Iannis Xenakis 'ın yapılarında müzik ile mimarlık ilişkisini kurgularlarken kullandığı parametrelerin neler olduğunun ortaya koyulması sağlanarak bir yapıda müzik ile ilişki kurulurken matematiksel kurgunun nasıl strüktüre edilmesi gerektiği konusunda literatüre katkı sağlanması amaçlanmıştır.

\subsection{Iannis Xenakis ve Tasarlamış Olduğu Yapılar}

Savaş sonrası en önemli avangard bestecilerden biri olarak tanınan Iannis Xenakis (29 Mayıs 1922- 4 Şubat 2001), müzik teorisyeni ve mimar-mühendistir. Xenakis, elektronik müziğin gelişimi üzerinde önemli bir etkiye sahip olmasıyla birlikte stokastik süreçler, set teorisi ve oyun teorisi gibi müzikte matematiksel modellerin kullanılmasına öncülük etmiştir. Resmileştirilmiş Müzik: Düşünce ve Matematikte Kompozisyon (1971) kitabı yazdığı çokça teorik yazı arasından en önemli kitaplarından biri olarak kabul görmektedir (URL-2). Mimarlık mesleğindeki ilk çalışmalarını Le Corbusier ile birlikte yapan Xenakis'in Sainte Marie de La Tourette ve Xenakis'in tek başına tasarladığı Expo 58'deki Philips Pavilion en önemli eserlerindendir.

Iannis Xenakis'in tasarlamış olduğu yapılarda müzik ile mimarlık arakesitinde yaklaşımlar sergilediği bariz bir şekilde görülmektedir. Müzisyen oluşu ve müzik ile matematiğin kompozisyonu 
hakkında çokça araştırma yapmış ve bu alanda teorik yazılar yazmış olması, mimari eserlerinde mimarlık ve müziğin alt veri tabanında yer alan matematiksel kurgulardan yararlanıp disiplinler arası tasarım yaklaşımını benimsemesine yol açmıştır. Çalışma kapsamında Iannis Xenakis’ in tasarlamış olduğu yapılardan; Isthmia Prime Motel, La Tourette Manastırı, Philips Pavyonu ve Villa Mache incelenmiştir. Seçilen yapı örnekleri, Iannis Xenakis’ in müzik mimarlık ilişkisini en iyi yansıtan yapıları olarak ün yapmış olan ve aynı zamanda müzik ve mimarlık kurgusunu bina tasarıma konu alan örnekler arasında alanında önem taşıyan eserlerdendir.

Iannis Xenakis, Isthmia Prime Motel'in tasarım kurgusunu oluştururken geometri ve yapı strüktüründen yararlanmıştır. 1969 yılında Yunanistan, Isthmia 'da yapılmış olan binanın odalarının planları yakınında bulunan Korint körfezinin güzel manzaralarının seyrini en üst düzeye çıkarmak için ana eksene eğik olarak düzenlenmiştir. Binanın zemin katında bulunan sütunlar üstte yer alan 2 katlı ana blokları desteklemektedir. Binanın düz çatısında tasarlanmış olan üçgen beton antiloplar, antik çağın çiçek anemisinin esinlenilmiştir. Zemin katta sadece hizmet alanları ve resepsiyon yer alan bina yıldız şeklinde bir gölet alanı ile yapı içerisinde bir yeşil alan su öğesi birleşimi ile kullanıcılara kolay ulaşılabilen bir nefes alma alanı sağlamaktadır.

1960 yılında Lyon, Fransa 'da yapılmış olan La Tourette Manastırı, müzik ve mimarlık ilişkisini tasarımda strüktür ve cephe kurgusunun tasarımında vurgu yaparak yansıtmıştır. Tasarım yaklaşımı olarak altın oran mantığını içinde barındıran bir oranlama sistemi ile müzikal ve poliritmik bir çözüm kullanmıştır. Le Corbusier, Fibonacci serisi ve altın oran mantı̆̆ını içinde barındırarak tasarlamış olduğu oranlama sistemini Modulor kitabında tüm detaylarıyla anlatmaktadır. Xenakis yapıyı tasarlarken Modulor'de anlatılan oranlama sisteminden yararlanmıştır. Modulor 'un Xenakis 'in müzisyen kişiliğini ortaya koyması ile dinamik bir hal alması, müzikal ve poliritmik bir çözüme yol açmıştır. Batı cephesini dört kademeli bir kontrpuandan oluşan yapı 'camların müzikali' olarak isimlendirmiştir (Özdemir, 2009: 44).

1958 yılında Brüksel, Hollanda'da yapılmış olan Philips Pavyonu, bir ses mekân ürünü olup, müziğin üç boyutlu tasarımının ele alınarak oluşturulmuş olan matematiksel kurgusunun yapı strüktürünü meydana getirmesi ile üretilmiştir. Matematik, müzik ve performansın iç içe geçtiği bu yapı gerçek bir "donmuş müzik” yapısıdır. Genellikle müzik iki boyutuyla ele alınırken, yapıda hem kullandığı ileri matematik ve geometri sayesinde hem de strüktürünü tanımlayan kendine özel yazılmış müziğiyle üçüncü boyutu tasarımda hissedilir kılmıştır. Ortaya çıkan ürün dünyanın ilk tümel sanat yapıtı niteliğini taşımaktadır. Yapı tasarımında mimarlık ve müziğin tasarımdaki kurgusu kopya/öykünme tekniği ile matematiksel verilerin bilgisayar destekli programlar aracılığıyla dizayn 
Çolak, B.B., ve ark., Uluslararası Doğu Anadolu Fen Mühendislik ve Tasarım Dergisi / International Journal of Eastern Anatolia Science Engineering and Design (IJEASED)

edilmesi ile oluşturulmuştur. Tasarımın çıkış noktası müziktir. Geometrik şekiller yardımıyla müzik ile mimarlık arasındaki ilişki kompozisyonu kurulmuştur.

1977 yılında Lefkes, Amorgos Island, Yunanistan'da yapılmış olan Villa Mache projesi tasarımı; plan üzerinde bağımsız gibi kurgulanmış görünse de kendi içerisinde matematiksel verilere dayanmaktadır. Iannis Xenakis'in kızı ve kızının eşi Fransız besteci Francois-Bernard Mache için tasarladığ1, modernizm ve gelenekselin bütünleştiği, fonksiyona göre şekillenen geometrik şekillerin her biri bir mekânı tanımlamaktadır. Plan üzerinde bağımsız gibi kurgulanan tasarım kendi içerisinde matematiksel verilere dayanmaktadır. Yapının karakteristik pencereleri, güneşini kontrol etmenin yanı sıra tasarım kurgusunun bir parçasıdır. Çıkış noktası müzisyen ve müzik olan tasarım, doğanın getirdiği çevresel veriler ile müzik ilişkisi kurup cephede doluluk boşluklarla ritmi yakalamıştır. Kompozisyon geometrik şekiller ile sağlanmıştır. Yapı formun şekillenmesindeki en önemli etkenler; ritim ve armoni uyumunu sağlamak için cephe ve plan düzleminde oluşturulan kurgudur.

İncelenen bina örneklerin fotoğrafları, çizimleri, yapım yılı, konumu ve mimari özellikleri aşağıda Tablo 1'de gösterilmektedir. Tablo 1'de tasarım yaklaşımı ve mimari özellik olarak çalışma kapsamında belirlenen ana başlıklar ve alt parametrelerinden örneklerin hangilerini kapsadığı belirtilmiştir.

Tablo 1. İncelenen örneklerin fotoğrafları, çizimleri, yapım yılı, konumu ve mimari özellikleri

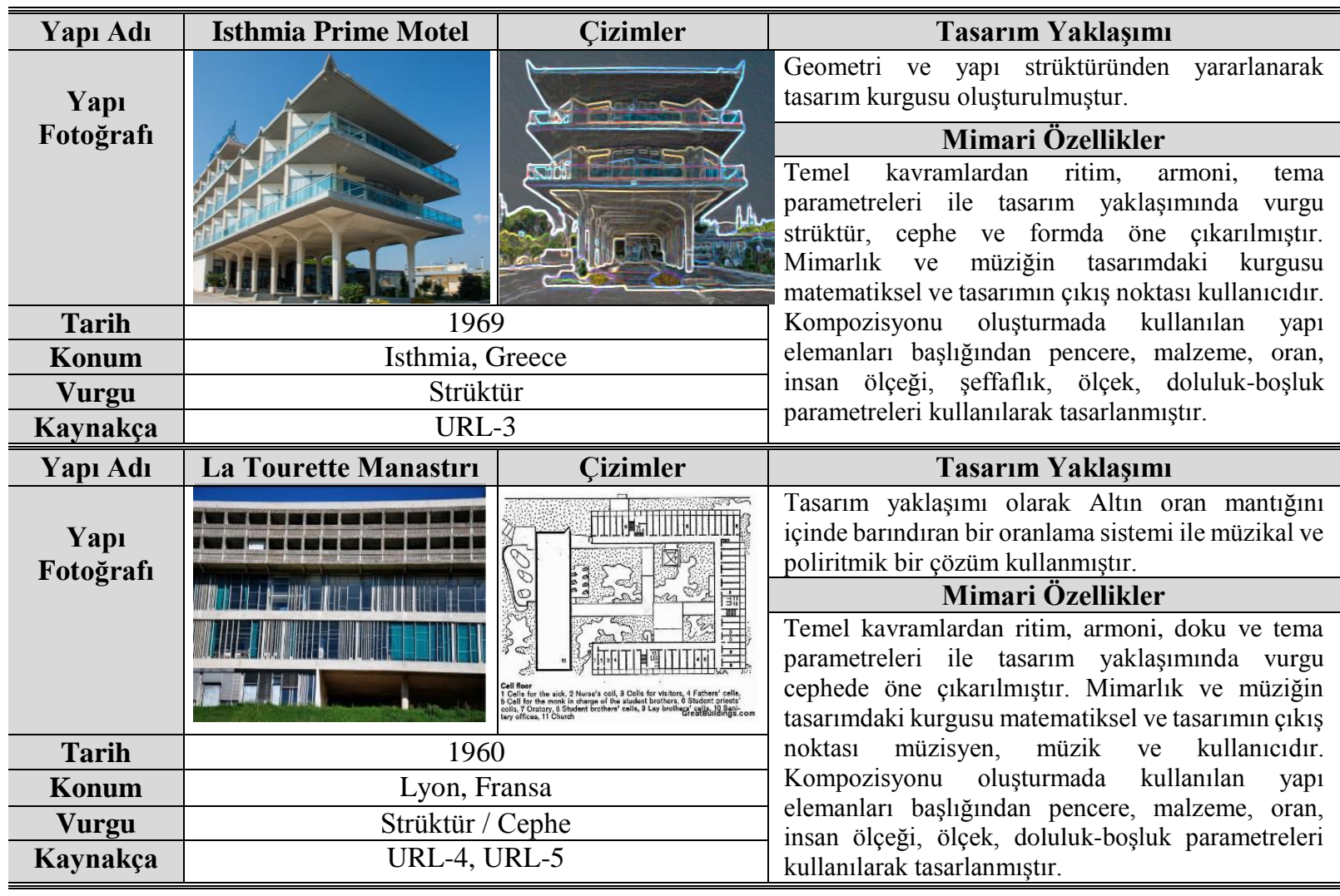




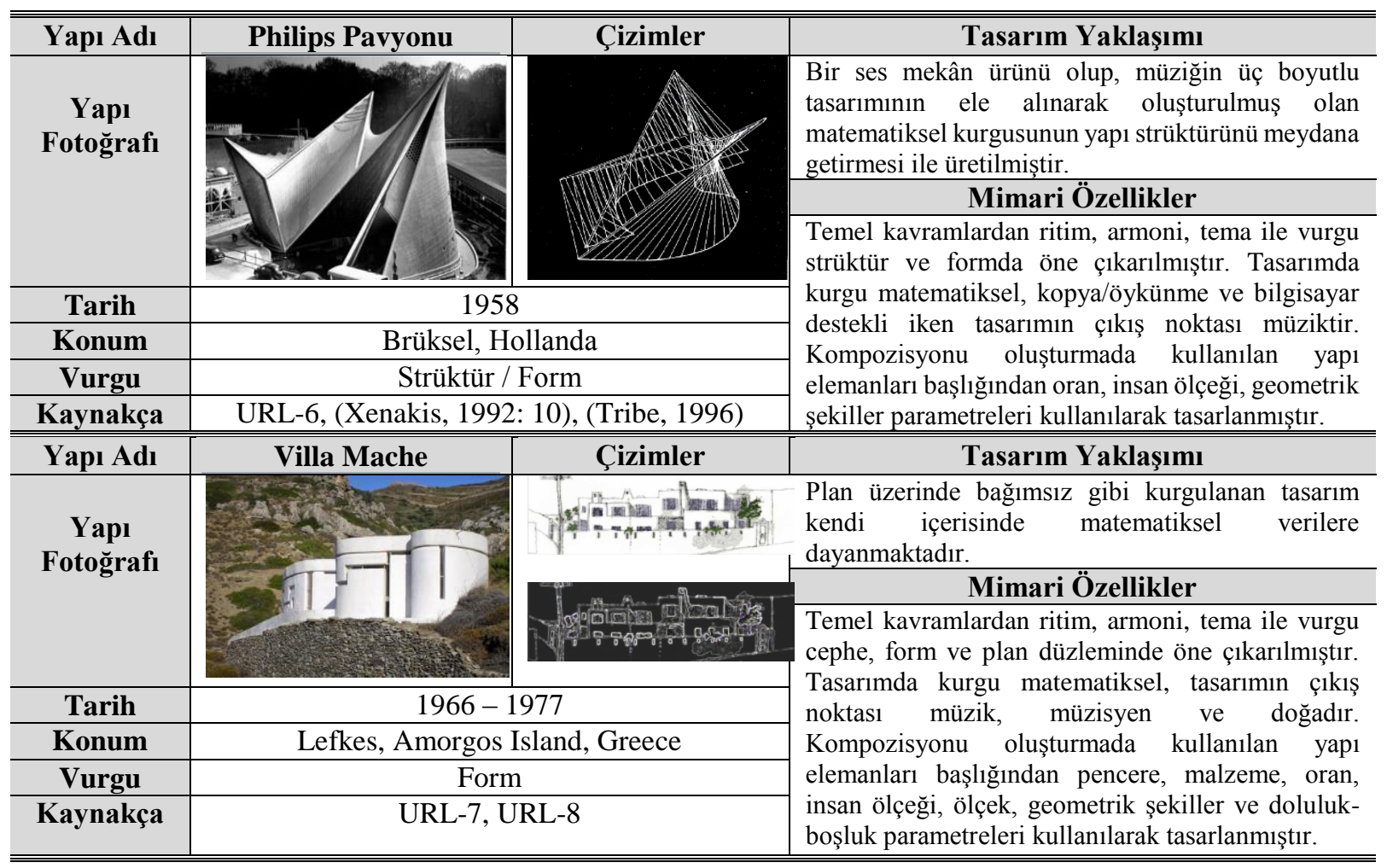

\section{Araştırma Bulguları}

Müzik ve mimarlık disiplinlerinin ara kesitindeki temel kriterler mimarlık ve müzikte kompozisyon ile ilgili temel kavramlar, tasarım yaklaşımda vurgu, mimarlık ve müziğin tasarımdaki kurgusu, tasarımın çıkış noktası, müzik ve mimarlık ilişkisi kompozisyonu oluşturmada kullanılan yapı elemanları ana başlıkların alt başlıklardaki parametreler dahilinde Iannis Xenakis' in tasarlamış olduğu örnekler Tablo 2'de incelenmiştir. 
Çolak, B.B., ve ark., Uluslararası Doğu Anadolu Fen Mühendislik ve Tasarım Dergisi / International Journal of Eastern Anatolia Science Engineering and Design (IJEASED)

(2021) 3(1):282-297

Tablo 2. Parametreler dahilinde Iannis Xenakis’ in tasarlamış olduğu örnekler incelenmesi

\begin{tabular}{|c|c|c|c|c|c|c|c|c|}
\hline \multirow[t]{2}{*}{ Yapı Adı } & \multicolumn{4}{|c|}{$\begin{array}{l}\text { Mimarlık ve Müzikte Kompozisyon ile İlgili Temel } \\
\text { Kavramlar }\end{array}$} & \multicolumn{4}{|c|}{ "Tasarım Yaklaşımda Vurgu } \\
\hline & Ritim & Armoni & Doku & Tema & Strüktür & Cephe & Form & $\begin{array}{l}\text { Plan } \\
\text { Düzlemi }\end{array}$ \\
\hline $\begin{array}{l}\text { Isthmia Prime } \\
\text { Motel }\end{array}$ & $\square$ & $\square$ & & $\square$ & $\square$ & $\square$ & $\square$ & \\
\hline $\begin{array}{l}\text { La Tourette } \\
\text { Manastırı }\end{array}$ & $\square$ & $\square$ & $\square$ & $\square$ & & $\nabla$ & & \\
\hline $\begin{array}{l}\text { Philips } \\
\text { Pavyonu }\end{array}$ & $\square$ & 口 & & $\square$ & $\square$ & & $\square$ & \\
\hline Villa Mache & $\square$ & $\square$ & & $\square$ & & $\nabla$ & $\square$ & $\square$ \\
\hline \multirow{2}{*}{ Yapı Adı } & \multicolumn{4}{|c|}{ Mimarlık ve Müziğin Tasarımdaki Kurgusu } & \multicolumn{4}{|c|}{ Tasarım Çıkış Noktası } \\
\hline & $\begin{array}{l}\begin{array}{l}\text { Matemati } \\
\text { ksel }\end{array} \\
\end{array}$ & Renk & $\begin{array}{l}\text { Kopya/ } \\
\text { Öykünme }\end{array}$ & $\begin{array}{l}\text { Bilgisayar } \\
\text { Destekli }\end{array}$ & $\begin{array}{l}\text { Müzisyen } \\
\text { Çıkışlı } \\
\end{array}$ & $\begin{array}{l}\text { Müzik } \\
\text { Çıkışlı }\end{array}$ & $\begin{array}{l}\text { Doğa } \\
\text { Çıkışlı }\end{array}$ & $\begin{array}{l}\text { Kullanıcı } \\
\text { Çıkışlı }\end{array}$ \\
\hline $\begin{array}{l}\text { Isthmia Prime } \\
\text { Motel }\end{array}$ & $\square$ & & & & & & & $\square$ \\
\hline $\begin{array}{l}\text { La Tourette } \\
\text { Manastırı }\end{array}$ & $\square$ & & & & $\square$ & $\square$ & & $\square$ \\
\hline $\begin{array}{l}\text { Philips } \\
\text { Pavyonu }\end{array}$ & $\square$ & & $\square$ & $\square$ & & $\nabla$ & & \\
\hline Villa Mache & $\square$ & & & & $\square$ & $\square$ & $\square$ & \\
\hline \multirow[t]{2}{*}{ Yapı Adı } & \multicolumn{8}{|c|}{ Müzik ve Mimarlık İlişkisi Kompozisyonu Oluşturmada Kullanılan Yapı Elemanları } \\
\hline & Pencere & Malzeme & Oran & $\begin{array}{l}\text { İnsan } \\
\text { Ölçeği }\end{array}$ & Şeffaflık & Ölçek & $\begin{array}{l}\text { Geometrik } \\
\text { Şekiller }\end{array}$ & $\begin{array}{l}\text { Doluluk } \\
\text { Boșluk }\end{array}$ \\
\hline $\begin{array}{l}\text { Isthmia Prime } \\
\text { Motel }\end{array}$ & $\square$ & $\square$ & $\square$ & $\square$ & $\square$ & $\square$ & & $\square$ \\
\hline $\begin{array}{l}\text { La Tourette } \\
\text { Manastırı }\end{array}$ & $\square$ & $\square$ & $\square$ & $\square$ & & $\square$ & & $\square$ \\
\hline $\begin{array}{l}\text { Philips } \\
\text { Pavyonu } \\
\end{array}$ & & & $\square$ & $\nabla$ & & & $\square$ & \\
\hline Villa Mache & $\square$ & $\square$ & $\square$ & 口 & & $\nabla$ & $\square$ & $\square$ \\
\hline
\end{tabular}

Isthmia Prime Motel örneğinde tasarım yaklaşımında vurgu strüktürle sağlanırken strüktürün etkisi yapının tüm cephesini ve formunu etkilemiştir. Kullanıcı çıkışlı tasarımı ile kompozisyon; ritim, armoni ve tema kavramları ile sağlanmıştır. Mimarlık ve müziğin tasarımdaki kurgusu matematiksel olup, kompozisyon oluşturulurken oran ve insan ölçeği dikkate alınmıştır. Yapı elemanı kullanımında şeffaflık ön plana çıkarılmıştır.

Altın oran mantığını içinde barındıran La Tourette Manastırı batı cephesi dört kademeli bir kontrpuandan oluşan tasarım yaklaşımı olarak cephe etkisini ön plan çıkarıp 'camların müzikali' olarak isimlendirmiştir. Ritim, armoni, doku ve tema kavramları ile kompozisyon oluşturulmuştur. Tasarımın ilk çıkış noktası müzisyen ve müzik olan yapıda, yapı elemanları kompozisyonu oluşturulurken; oran, ölçek, insan ölçeği ve doluluk- boşluk dikkate alınmıştır.

Philips Pavyonu “donmuş müzik” yapısı olarak adlandırılan yapı; matematik, müzik ve performansın iç içe geçtiği, ileri matematik ve geometri sayesinde strüktürünü tanımlarken anlattığ 
müziği üç boyutlu olarak tasarımda hissedilebilmesini mümkün kılmıştır. Bu etkiyi strüktür tasarımı yardımıyla sağlamıştır. Mimarlık ve müziğin tasarımdaki kurgusu; matematik, kopya/öykünme ve bilgisayar destekli sağlanmıştır. Tasarımın çıkış noktası müziktir. Oran, insan ölçeği ve geometrik şekillerden yararlanılarak kompozisyon oluşturulmuştur.

Villa Mache; fonksiyona göre şekillenen geometrik şekillerin her biri bir mekânı tanımlarken, plan düzlemindeki matematiksel verilerden dolayı yapının formunun geometrik şekli de kurgusunun bir parçası halini almıştır. Tasarımın çıkış noktası müzisyen, müzik ve doğadır. Ritim, armoni ve tema kavramları ile kompozisyon oluşturulmuştur.

\section{Sonuç}

Mimarlık, müzik ve matematik disiplinlerinin çakışma noktası teknik veri ve bilgisayar desteğidir. Matematiksel sayısal veriler sayesinde müzik ve mimarlıkta tasarım kurgularında oranlı, ölçülü olma durumunda gerçekleşmektedir. Değişen ve gelişen teknoloji sayesinde günümüzde bu kurgu; teknik bilgiler dahilinde bilgisayar destekli ortamlarda tasarımın alt verisi olarak hız kazanmıştır.

Araştırma bulguları bölümünde 'Parametreler dahilinde Iannis Xenakis' in tasarlamış olduğu örnekler incelenmesi' başlıklı Tablo 2 'de değerlendirmesi yapılan verilerin özet bir sonuç tablosu niteliğinde olan Tablo 3'te; çalışma kapsamında incelenen örneklerin ana başlıklar altında yer alan kriterlerinin sayısal oranlara dönüştürülerek irdelenmesi yer almaktadır.

Tablo 3. Özet sonuç tablosu / Parametrelerin sayısal oranlara dönüştürülerek irdelenmesi

\begin{tabular}{l|l|l|l|l}
\hline & $\begin{array}{l}\text { Isthmia } \\
\text { Prime } \\
\text { Motel }\end{array}$ & $\begin{array}{l}\text { La } \\
\text { Tourette } \\
\text { Manastırı }\end{array}$ & $\begin{array}{l}\text { Philips } \\
\text { Pavyonu }\end{array}$ & $\begin{array}{l}\text { Villa } \\
\text { Mache }\end{array}$ \\
\hline \multirow{2}{*}{$\begin{array}{l}\text { Mimarlık ve Müzikte Kompozisyon ile İlgili } \\
\text { Temel Kavramlar }\end{array}$} & $3 / 4$ & $4 / 4$ & $3 / 4$ & $3 / 4$ \\
\cline { 2 - 5 } & $\% 75$ & $\% 100$ & $\% 75$ & $\% 75$ \\
\hline Tasarım Yaklaşımda Vurgu & $3 / 4$ & $1 / 4$ & $2 / 4$ & $3 / 4$ \\
\cline { 2 - 5 } & $\% 75$ & $\% 25$ & $\% 50$ & $\% 75$ \\
\hline \multirow{2}{*}{ Mimarlık ve Müziğin Tasarımdaki Kurgusu } & $1 / 4$ & $1 / 4$ & $3 / 4$ & $1 / 4$ \\
\cline { 2 - 5 } & $\% 25$ & $\% 25$ & $\% 75$ & $\% 25$ \\
\hline Tasarım Çıkış Noktası & $1 / 4$ & $3 / 4$ & $1 / 4$ & $3 / 4$ \\
\cline { 2 - 5 } & $\% 25$ & $\% 75$ & $\% 25$ & $\% 75$ \\
\hline \multirow{2}{*}{$\begin{array}{l}\text { Müzik ve Mimarlık İlişkisi Kompozisyonu } \\
\text { Oluşurmada Kullanıan Yapı Elemanları }\end{array}$} & $7 / 8$ & $6 / 8$ & $3 / 8$ & $7 / 8$ \\
\cline { 2 - 5 } Toplam Kriterlerden Karşılanan & $\% 87,5$ & $\% 75$ & $\% 37,5$ & $\% 87,5$ \\
\cline { 2 - 5 } & $\% 62,5$ & $\% / 24$ & $12 / 24$ & $17 / 24$ \\
\hline
\end{tabular}


Tablo 3 değerlendirildiğinde; 'Mimarlık ve Müzikte Kompozisyon ile İlgili Temel Kavramlar' başlığı altında bulunan 4 temel kriterden La Tourette Manastırı örneği \%100 'ünü karşılarken diğer örnekler \%75'ini karşıladığı görülmektedir. 'Tasarım Yaklaşımda Vurgu' başlığı altında yer alan kriterlerden en fazlasını \%75 oranla Isthmia Prime Motel ve Villa Mache örnekleri karşılarken en az kriteri \%25 oranla La Tourette Manastırı sağlamaktadır. 'Mimarlık ve Müziğin Tasarımdaki Kurgusu' başlığı parametrelerinden Philips Pavyonu \%75'ine sahipken diğer örnekler \%25'ini sahiptir. 'Tasarım Çıkış Noktası' başlığ 1 altındaki kriterlerden \% 75 'ini La Tourette Manastırı ve Villa Mache sağlarken Isthmia Prime Motel ve Philips Pavyonu örnekleri \%25'ini sağlamaktadır. 'Müzik ve Mimarlık İlişkisi Kompozisyonu Oluşturmada Kullanılan Yapı Elemanları' başlığı altında 8 parametre yer almaktadır. Bu parametrelerden en fazlasını \%87,5 oranla Isthmia Prime Motel ve Villa Mache karşılarken en azını \%37,5 oranla Philips Pavyonu karşılamaktadır. Çalışma kapsamında incelenen ana başlıklar altında belirlenmiş toplam 24 parametre bulunmaktadır. $\mathrm{Bu}$ parametrelerden tasarımında en fazla oranda bulunduran Villa Mache kriterlerin \%70,83'ine sahiptir. Villa Mache'yi takiben \%62,5 oranla Isthmia Prime Motel ve La Tourette Manastırı yer alırken Philips Pavyonu parametrelerin yarısını karşılayarak \%50 oranla tabloda yerini almıştır.

Çalışması kapsamında yer alan tablolar genel olarak değerlendirildiğinde; müzik ve müzikte kompozisyon oluşturma ile ilgili temel kavramlardan olan ritim, armoni ve temanın tüm örneklerde yer aldığını görürken, doku kavramının sadece La Tourette Manastırı örneğinde yer aldığı görülmektedir. Tasarım yaklaşımında vurgu tasarım özelinde değişkenlik göstermektedir. Mimarlık ve müziğin tasarımdaki kurgusunun tüm örneklerde matematiksel verilere dayandığı görülmektedir. Tasarımların yapım yılları göz önüne alındığında bilgisayar destekli tasarım kurgusunun sadece Philips Pavyonu örneğinde bulunduğu görülmektedir. Günümüz koşullarında ise bilgisayar destekli tasarımın yapı kurgusunun bir parçası olduğu görülmektedir. Tasarımın çıkış noktasının yapı özelinde değişkenlik gösterdiği görülmüştür. Müzik ve mimarlık ilişkisi kompozisyonu oluşturmada kullanılan yapı elemanları başlığının alt parametrelerinden olan oran ve insan ölçeğinin tüm örneklerde önemsendiği görülmüştür. Tüm bu değerlendirmeden elde edilen bilgiler dahilinde özellikle müzik ve mimarlık ilişkisi kurulurken ritim, armoni ve temanın önemini, tasarımın altlığının matematiksel verilere dayandığı görülmekle birlikte yapı özelinde tasarımın çıkış noktasının ve tasarım yaklaşımındaki vurgunun değişkenlik gösterdiği görülmektedir.

Sonuç olarak; mimar bir müzisyen olan tasarımcı Iannis Xenakis 'ın yapılarında müzik ile mimarlık ilişkisini kurgularlarken kullandı̆̆ 
sağlanarak bir yapıda müzik ile ilişki kurulurken matematiksel kurgunun nasıl strüktüre edilmesi gerektiği konusunda literatüre katkı sağlanması amaçlanmıştır.

\section{Yazarların Katkısı}

Çalışmada her üç yazar da eşit oranda katkı sunmuştur.

\section{Çıkar Çatışması Beyanı}

Yazarlar arasında herhangi bir çıkar çatışması bulunmamaktadır. Araştırma ve Yayın Etiği Beyanı Yapılan çalışmada, araştırma ve yayın etiğine uyulmuştur.

\section{Teşekkür}

Bu çalışmanın özet bildirimi “18-21 Kasım 2020’de Karabük Üniversitesi, Mimarlık Fakültesi tarafından Safranbolu'da Uluslararası Mimarlık Araştırmaları Sempozyumu (ReseArch'20)" kongresinde sözlü sunum olarak sunulmuş olup, kongre üyelerine teşekkür ederiz.

\section{Kaynaklar}

AK, Ş. A., (2009). Türk Mûsikisi Tarihi. Akçağ Yayınları, Ankara.

Akkaş, S., (2000). Batı Müziğinde Nota Yazısı. Gazi Sanat Dergisi, sayı 1 s. 67-78, Ankara.

Bent, D. İan., (1991). The new Grove Dictionary of Music and Musicians. Glasgow: Oxford University Press. Cage, J., (1955). Experimental Music: Doctrine, I. M. A. Magazine, Londra.

Canbay, Alaattin vd. (2013). Müzik Kültürü. Ed. Zeki Nacakçı ve Alaattin Canbay. Ankara: Pegem Akademi. Corbusier, L., (2001). Bir Mimarlı̆̆a Doğru. İstanbul: Yapı Kredi Yayınları, 28-236.

Erözü, C., (2008). Mimari Donmuş Müziktir, Mimarlıkta Malzeme. TMMOB Mimarlar Odası İstanbul Büyükkent Şubesi, $10 \mathrm{Güz} / 2008$.

Evans, B., (1992). The Graphic Design of Musical Structure. Alabama University, United States of America. Güngör, K., (2015). Nota Yazısının Tarihsel Gelişimi. Sahne ve Müzik, 1.Bask1, 81-89.

Güran, Y., (2008). Müziğin Matematik ve Fraktal Geometri ile Olan İlişkisi. http://www.yalcinguran.com/2008/03/mziin-matematik-fraktalgeometriyle.html (14.08.2008)

Korkut, C. Y., (2011). Müzik ve Mimarlık İlişkisinde Etkileşimli Bir Parametrik Model. Yüksek Lisans Tezi, Yıldız Teknik Üniversitesi, Fen Bilimleri Enstitüsü, İstanbul.

Mimaroğlu, İ., (1987). Müzik Tarihi. Varlık Yayınları, İstanbul.

Özdemir, D., (2009). Müzik ve Mimarlı̆ğn Kompozisyon Bağlamında İncelenmesi. Yüksek Lisans Tezi, İstanbul Teknik Üniversitesi, Fen Bilimleri Enstitüsü, İstanbul.

Say, A., (2002). Müzik Sözlü̆̈̈̈. Ankara: Müzik Ansiklopedisi Yayınları.

Şentürk, L., (2004). Küre musikisi ve Pisagor Öncelleri. Arredamento Mimarlık, Boyut Yayınc1lı, İstanbul, 405: 73-75 05/2004.

Tribe, M., (1996). Space Calculated in Seconds. Princeton University Press, United States of America.

Vitruvius, (2015). Mimarlı Üzerine On Kitap. Ankara: Şevki Vanlı Mimarlık Vakfi, 6.Baskı, 4-103.

Xenakis, I. (1992). Formalized Music: Thoughts and Mathematics in Composition. New York: Pendragon Press, 4.

URL-1: www.beethovenlives.net, (Erişim Tarihi: 22 Mart 2020).

URL-2: http://architectuul.com/architect/iannis-xenakis, (Erişim Tarihi: 11 Mayıs 2020).

URL-3: http://architectuul.com/architecture/isthmia-prime-motel, (Erişim Tarihi: 10 Mayıs 2020). 
Çolak, B.B., ve ark., Uluslararası Doğu Anadolu Fen Mühendislik ve Tasarım Dergisi / International Journal of Eastern Anatolia Science Engineering and Design (IJEASED)

(2021) 3(1):282-297

URL-4: www.archidialog.com, (Erişim Tarihi: 14 Mayıs 2020).

URL-5: https://www.arkitektuel.com/la-tourette/,_Erişim Tarihi: 14 Mayıs 2020).

URL-6: www.mimarizm.com, (Erişim Tarihi: 16 Nisan 2020).

URL-7: http://amorgosarchitects.gr/, (Erişim Tarihi: 05 Mayis 2020).

URL-8: http://architectuul.com/architecture/villa-mache, (Erişim Tarihi: 06 Mayıs 2020). 